Nicole Simek, Hunger and Irony in the French Caribbean: Literature, Theory, and Public Life. Basingstoke, U.K.: Palgrave Macmillan 2016. ix + 201 pp. (Cloth US\$99.99)

This compelling and timely study proposes to read "hunger and irony together, as mutually elucidating and complicating terms” (p. 2). From the outset, however, Nicole Simek acknowledges the moral dilemma that an appraisal of irony ("a trope associated with playfulness, ambiguity, or deception") alongside hunger ("a threat to biological survival") would evoke (p. 2), if not explained through the capacity of irony to deploy the analytical potential of hunger. To achieve her authoritative pairing of this seemingly incompatible match and unravel a twist that is both ironic and fittingly accurate, she analyzes a diverse range of genres and forms, including "fiction, essay, manifesto, and photography" (p. 3). In twinning hunger and irony as critical tools to interrogate the complex and often dire concerns that suffuse the literature of Guadeloupe and Martinique, she builds on recent studies that have evaluated configurations of politics and aesthetics in discourses relating to food, consumption, hunger, and domination in the Caribbean literary imagination. She also acknowledges studies that invoke cannibalism as a dominant critical trope, a crucial site for Caribbean cultural identity and literary criticism. The book builds on Simek's previous work on the act of reading as consumptive practice and the interpretive ethics that undergird any engagement with Maryse Condé's varied oeuvre. Not surprisingly, then, Condés works dominate the list of texts sampled, along with writings by Patrick Chamoiseau.

Chapter 1 introduces the principal theoretical concepts bolstering her critical enterprise. Anchoring Hunger and Irony in paradigms deriving as much from Roland Barthes, Jacques Derrida, Édouard Glissant, and Slavoj Žižek as from postcolonial criticism more broadly, Simek grounds the study's persuasive argument in the varying registers and competing interpretations that can be ascribed to the deployment of hunger and irony in selected texts of the Francophone Caribbean tradition. Chapter 2 reads Condé's Histoire de la femme cannibale (2003) along with Chamoiseau's Solibo Magnifique (1988) in a move that underscores both novels as detective narratives. She centers her inquiry in the meanings that theorizing can help clarify, rightly identifying the scribal encroachment on oral culture that propels Solibo forward-a "parasite's hunger"-as an ironic "hunger for relationality" (p. 29). Simek concludes that Condé "brings irony to bear on the hunger of both artist and reader as it sets the question of literature's purpose within a tale of cannibalistic appetites" (p. 30). Chapter 3 seeks to evaluate the political function of literature through an examination of Chamoiseau's Écrire en pays dominé (1997) alongside Gisèle

(C) NJERI GITHIRE, 2019 | DOI:10.1163/22134360-09301029

This is an open access article distributed under the terms of the prevailing CC-BY-NC license 
Pineau's Folie, aller simple (2014). Taking on critics who confine the autobiographical genre to western traditions, Simek underscores the complexities involved in integrating politics with literary representations in self-ironizing ways. This chapter further evokes Condé's La vie sans fards (2012), and draws on the three works to explore the tension between urgency and agency and between transparency and opacity, and to interpret "Antillean self-writing as ironizing or rusing with autobiography" (p. 64).

Chapter 4 reviews the manifesto co-authored by Ernest Breleur and other Martinican cultural figures and intellectuals following the 2009 general strikes that sought to call attention to the high cost of living in the French overseas departments of Guadeloupe, Martinique, Guyane, and Réunion. Simek examines Manifeste pour les "produits" de haute nécessité with what might appear a rather odd pairing, Simone Schwarz-Bart's Ti-Jean L'horizon (1979), to highlight the interventions that irony can make in the face of a system become unjust to the point of oppressive. The two works considered in Chapter 5 , Chamoiseau's Un dimanche au cachot (2007) and Condé's La Belle Créole (2001), reveal "irony's ability to ruse with the given, with the constraints imposed by embodiment, pain, and history, in order to produce new dispositions and practices" (p. 122). Chapter 6 reviews Elmire des sept bonheurs (1998) by Chamoiseau with photos by Jean-Luc de Laguarigue together with Condé's Victoire: Les saveurs et les mots (2006) to emphasize "gaps and silences" (p. 15o) in historical records, including their implications for fictional interpretation. As Simek affirms, this chapter - and indeed the entire book — seeks to answer the question: "what modes of irony ... might best attend to a hunger for a justly 'post'-colonial society?" (p. 150). Her conclusion reinforces what had appeared an unlikely symbiosis, asserting that the texts analyzed "show that irony's fork resides in its ability to respond and generate a hunger for relation" (p. 177). Hunger and Irony is a vital component of ongoing Caribbean literary conversations, and of prevalent postcolonial debates more generally.

\section{Njeri Githire}

African American and African Studies, University of Minnesota-Twin Cities ngithire@umn.edu 